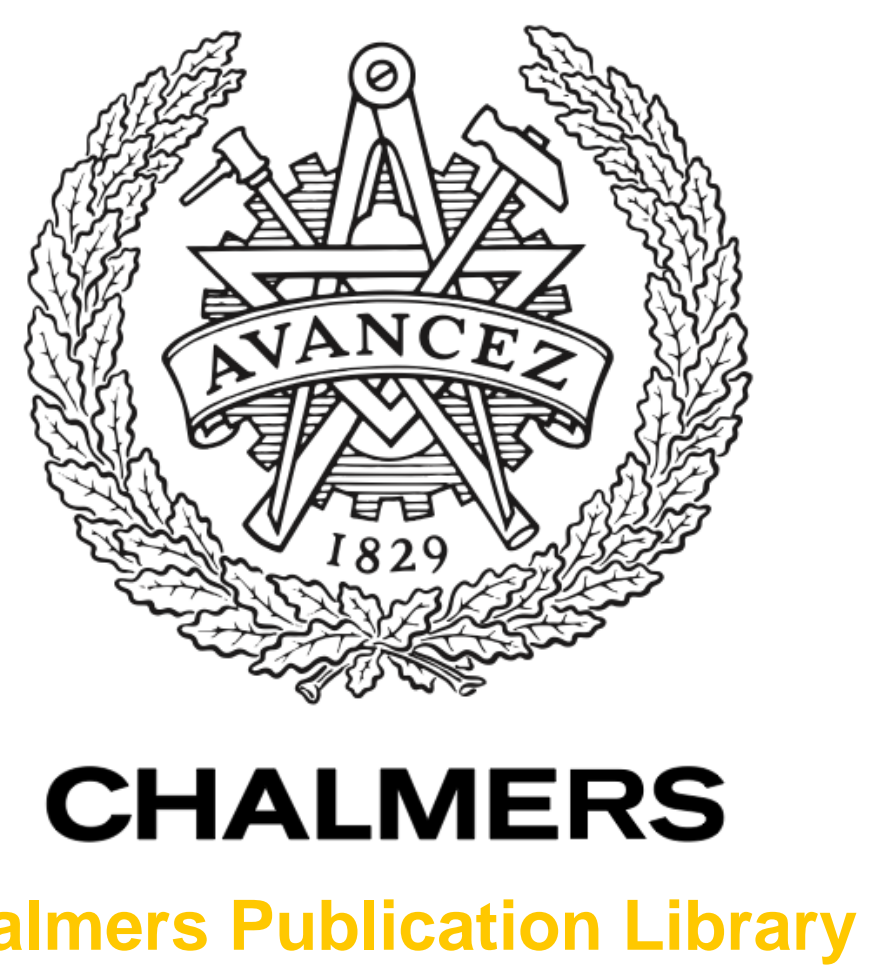

Chalmers Publication Library

Initiating Quality Management in a Small Company

This document has been downloaded from Chalmers Publication Library (CPL). It is the author's version of a work that was accepted for publication in:

The TQM Journal (ISSN: 1754-2731)

Citation for the published paper:

Assarlind, M. ; Gremyr, I. (2016) "Initiating Quality Management in a Small Company". The TQM Journal, vol. 28(2), pp. 166-179.

http://dx.doi.org/10.1108/TQM-01-2014-0003

Downloaded from: http://publications.lib.chalmers.se/publication/214047

Notice: Changes introduced as a result of publishing processes such as copy-editing and formatting may not be reflected in this document. For a definitive version of this work, please refer to the published source. Please note that access to the published version might require a subscription.

Chalmers Publication Library (CPL) offers the possibility of retrieving research publications produced at Chalmers University of Technology. It covers all types of publications: articles, dissertations, licentiate theses, masters theses, conference papers, reports etc. Since 2006 it is the official tool for Chalmers official publication statistics. To ensure that Chalmers research results are disseminated as widely as possible, an Open Access Policy has been adopted.

The CPL service is administrated and maintained by Chalmers Library. 


\title{
Initiating Quality Management in a Small Company
}

\author{
Marcus Assarlind*,marcus@assarlind.se \\ Division of Quality Sciences, Chalmers University of Technology \\ Ida Gremyr*, ida.gremyr@chalmers.se \\ Division of Quality Sciences, Chalmers University of Technology
}

\begin{abstract}
"This article is (C) Emerald Group Publishing and permission has been granted for this version to appear at Chalmers publication library. Emerald does not grant permission for this article to be further copied/distributed or hosted elsewhere without the express permission from Emerald Group Publishing Limited."
\end{abstract}

\section{Purpose}

The purpose of this paper is to identify critical aspects of Quality Management (QM) adoption in a small company. QM is more widely applied in large companies than in small ones. Previous research has pointed to QM ideas as sound and valid for small companies, but that many such initiatives fail because of poor implementation. With scarcity of resources and expertise, it is critical to study how QM can be initiated in small companies with often sceptical ownermanagers.

\section{Design/methodology/approach}

This paper is based on a single case study of a small company; data has been collected through two sets of interviews: one in late 2009 and one in mid-2012, as well as project reports and public financial data. This allows for a study of the adoption process over time.

\section{Findings}

This study points to four critical areas when initiating QM work in a small company: the importance of initiation, the importance of contextualisation, QM adoption as an iterative process, and the need for external support.

\section{Originality/value}

This paper highlights the importance of overcoming small business owners' reluctance towards QM. Most research on QM initiatives in small companies has focused on the stages that follow an actual decision to begin a QM initiative. This paper shows that it is critical to carefully consider the stages leading to the decision. Further, it contributes with a case study on a small company, otherwise uncommon in QM research.

Keywords: quality management, small to medium sized enterprises, small firms, adoption process, initiation, implementation, continuous improvements

Article Classification: Research Paper 


\section{Introduction}

"A small business is not a little big business", as Welsh and White (1981, p. 18) said in the title of their article. Small organisations have their own set of strengths and weaknesses, notably scarce resources (not only financial, but also knowledge and personnel resources) and personalised management (Bridge et al., 2003; Rahman and Tannock, 2005). Quality management $(\mathrm{QM})$ is comparatively well explored among large companies, but not so among small ones (e.g., Beheshti and Lollar, 2003; Kuratko et al., 2001; Thomas and Webb, 2003; Yusof and Aspinwall, 1999). Nevertheless, QM ideas are identified as promising contributions to SMEs (e.g., Antony, 2008; Brue, 2006; Hansson and Klefsjö, 2003; Martinez-Costa and Jimenez-Jimenez, 2009; Valmohammadi, 2011).

WashCo is a small Swedish company that in short time managed to triple its capacity and double its profits, establishing itself as a market leader in its niche. The company has in recent years reorganised its operations according to modern operations practices, for example, applying Six Sigma. However, what is interesting is not what they did - which would be almost trivial to any scholar or practitioner versed in the field - but how they almost did not do it.

In the WashCo case, adopting QM practices had potential and the owner-manager recognised the need for change, yet these methods that were common among large companies, such as car manufacturers, felt far from his reality. However, after years of persuasion, the owner-manager yielded and has not looked back.

As means of improving organisations' operations, QM initiatives have come under many names, such as Six Sigma, business excellence, and lean manufacturing (Brown, 2013; Dahlgaard and Dahlgaard-Park, 2006). Hansson and Klefsjö (2003) argued that although QM ideas are sound, many initiatives in SMEs fail because of poor implementation. In addition, as SMEs often has a fewer knowledge and personnel resources (Bridge et al., 2003), they may perhaps not even start QM efforts. Although management involvement is a common theme in literature on QM in SMEs (e.g., Beheshti and Lollar, 2003; Hansson and Klefsjö, 2003; Tannock et al., 2002), how QM should be initiated in companies with sceptical owner-managers has been largely ignored.

The purpose of this paper is to identify critical aspects of an adoption of a QM initiative in a small company. QM adoption is in this paper defined as a process through which an organisation gains initial knowledge of, implements, and integrates QM. The process starts when an organisation becomes aware of QM, referred to as the initiation stages (Zaltman et al., 1973). This paper includes background on QM in SMEs, and adoption processes, as well as elaborations on research methods before describing the case studied. An analysis of the case is followed by a discussion and conclusions.

\section{Theoretical framework}

The following theoretical framework begins with an overview of previous research on QM in SMEs, focusing on the adoption of a QM initiative. To support the analysis of the WashCo QM initiative, this framework also addresses research on adoption processes in general.

\section{Quality Management in SMEs}

Assarlind and Gremyr (2014) suggested that research on factors supporting QM in SMEs can be clustered into six categories: contextualisation, gradual implementation with realistic goals, involvement and training of employees, involvement of external support, management involvement, and fact-based follow-up. 
A first step towards any QM adoption is to contextualise the organisation's needs (Ghobadian and Gallear, 1997; Hansson and Klefsjö, 2003; Tannock et al., 2002) in order to frame the implementation that should itself connect closely to the company's existing goals (Rahman and Tannock, 2005; Salaheldin, 2009; Thomas and Webb, 2003). However, in an SME with scarce resources, QM should be adopted gradually and in a monitored fashion, rather than attempting to implement everything at once (Ghobadian and Gallear, 1997; Struebing and Klaus, 1997; Yusof and Aspinwall, 2000).

Small companies' employees and management usually have a high degree of visibility and closeness (Ahire and Golhar, 1996; Ghobadian and Gallear, 1997), which can facilitate QM (Pun and Jaggernath-Furlonge, 2012). Despite this closeness, QM initiative information must be actively communicated (Kumar and Antony, 2008; Rahman and Tannock, 2005) to ensure everyone works towards common goals (Rahman and Tannock, 2005). Although employee involvement and training is critical, the company may sometimes need support from an external QM expert. An SME may not be able to employ a skilled full-time improvement expert (Yusof and Aspinwall, 2000); however, there are several alternative ways of acquiring external support, such as contacting governing bodies, which are often eager to support SMEs (G. L. Lee and Oakes, 1995; Rahman and Tannock, 2005), universities, or sharing resources through company networks (Ahlström-Söderling, 2003; Thomas and Webb, 2003).

Managers should ensure the QM initiative is designed to support the company's specific needs and, accordingly, must drive the initiative with devotion (Hansson and Klefsjö, 2003). Part of this drive is to follow-up with data collection (for example, cost and yield) to understand QM progress (Kuratko et al., 2001; Salaheldin, 2009). Since companies do not exist in a vacuum, managers may attain valuable insight by benchmarking other companies (Salaheldin, 2009; Struebing and Klaus, 1997; Tannock et al., 2002).

Many of these areas can be identified in a typical QM framework (Bergman and Klefsjö, 2010; Dean and Bowen, 1994; Hackman and Wageman, 1995), albeit with slightly different emphases, such as an overall focus on resource scarcity or the need for external support, both of which are common SME characteristics (e.g., Jarvis, 2006; Welsh and White, 1981). Also notable is the lack of emphasis on customer focus, which otherwise is at the core of typical QM frameworks (Bergman and Klefsjö, 2010; Dean and Bowen, 1994; Hackman and Wageman, 1995). SMEs often already have a naturally strong, implicit customer focus (Danes et al., 2008), which could be why this area was not emphasised in earlier research.

\section{Adoption Processes}

An innovation, whether technical (Kimberly and Evanisko, 1981) or managerial (Birkinshaw et al., 2008), is the adoption of something new into an organisation. Although all innovation adoptions are unique, research has explicated general ideas regarding the stages in such a process. Zaltman et al. (1973) divided innovation adoption into initiation and implementation. Initiation includes everything leading up to the decision to adopt an innovation, including creating awareness and shaping attitudes (Zaltman et al., 1973). Implementation follows the adoption decision and includes the ways in which the innovation as well as the organisation are subsequently modified (Damanpour, 1992). From the perspective of individuals, predominantly decision-making managers, Rogers (2003) further broke down the innovation adoption process 
into knowledge, persuasion, decision, implementation, and confirmation (

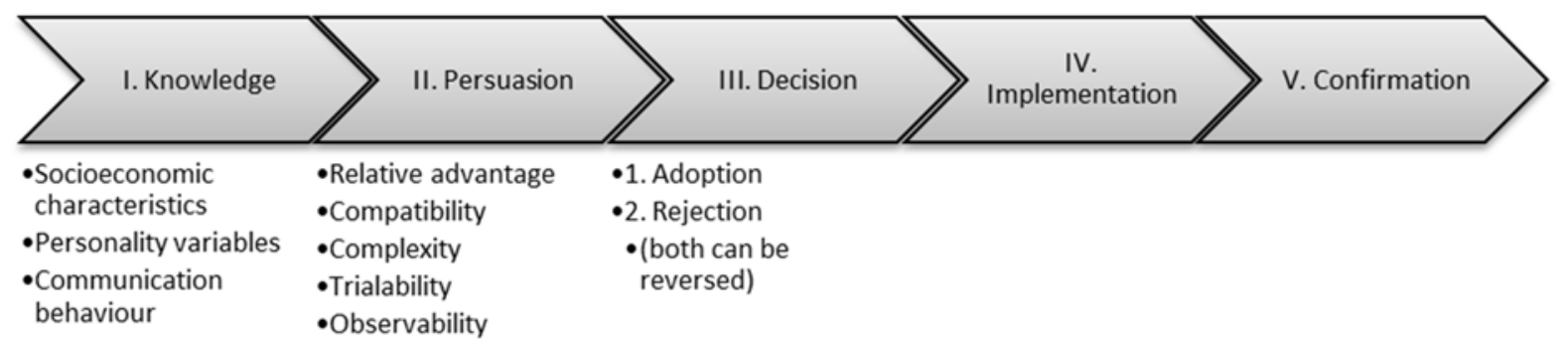

Figure 1).

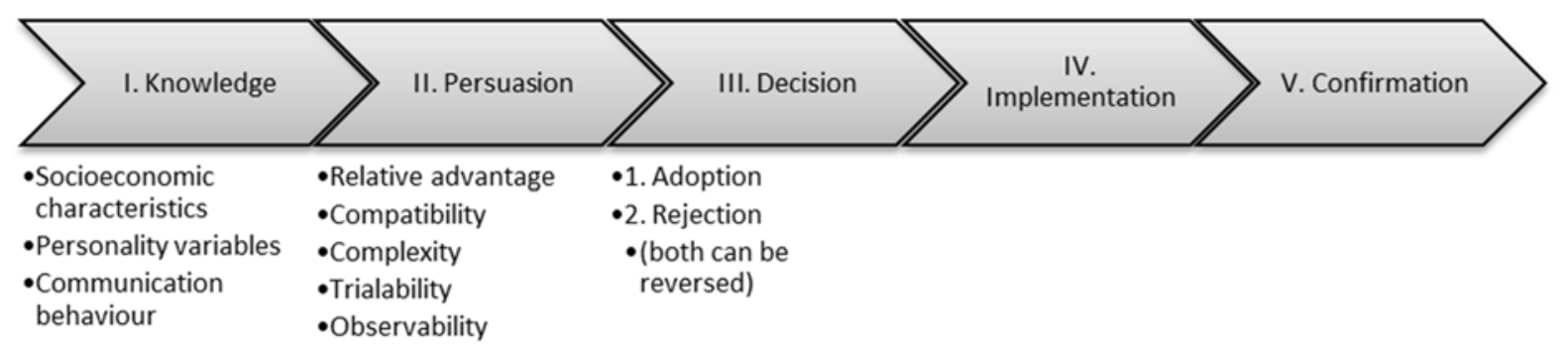

Figure 1. An innovation decision model, adapted from Rogers (2003); the bullet points under the knowledge and persuasion stages are innovation characteristics that can affect these respective stages.

The knowledge stage is when an individual learns about a new idea, or experiences a need. If the new idea is not perceived as relevant, the process ends. During persuasion, the individual forms an opinion on the idea, one that may be based on reflections on the idea's suitability, or on others' opinions. Rogers (2003) argued that during the persuasion stage, the individual is influenced by relative advantage, compatibility, complexity, experimentation, and observability of the idea. At the decision stage, individuals determine either to try an idea, or reject it (although the decision may later be reversed). Following acceptance of the idea, the innovation is implemented. In the confirmation stage, the individual seeks to evaluate whether the decision was correct, and may reverse the decision. Rogers (2003) also suggested that prior conditions play a role in the adoption process, specifically previous practices, needs/problems, innovativeness, and social system norms.

If the factors that support QM adoption in SMEs are related to Rogers's innovation decision model

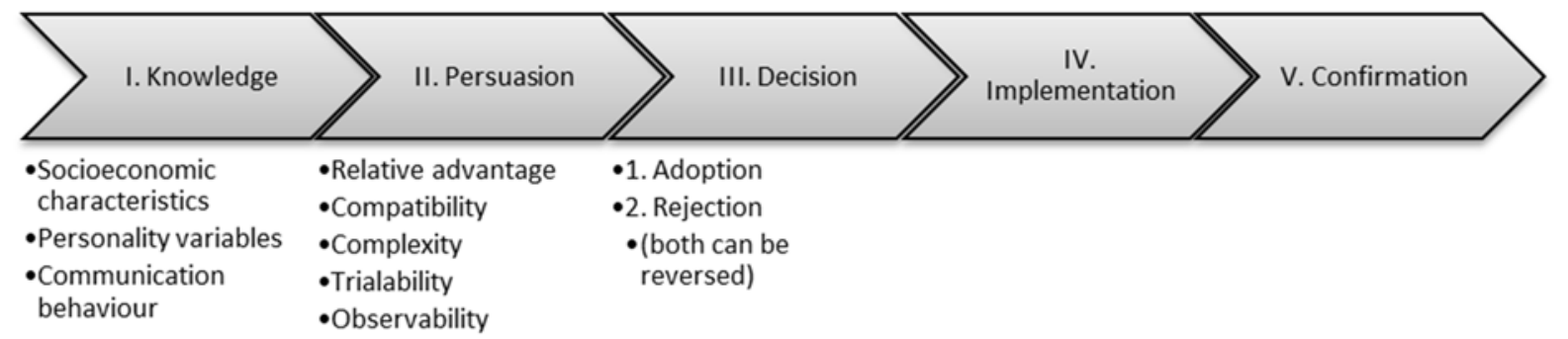

Figure 1), few explicitly discuss the stages preceding implementation. Hence, research focusing on QM in SMEs has somehow neglected the initial stages (Zaltman et al., 1973) that lead up to a decision on whether or not to adopt QM. 


\section{Method}

To address the adoption process, this study required understanding of its context over time (Halinen et al., 2012). For this purpose of understanding a phenomenon in a specific setting in an in-depth manner, a descriptive case study approach was applied (Dane, 1990; Dubois and Gadde, 2002; Eisenhardt, 1989; Yin, 2009).

Primary data was collected at two points in time through interviews at WashCo, a company with 17 employees. A first round of interviews was conducted in late 2009 with four interviewees: the owner-manager (referred to as John), the production manager, the change leader (referred to as Peter), and one operator. The first three were the most involved in the improvement journey, and the operator contributed a shop-floor perspective. Three interviews were conducted on-site, while Peter, who had resigned from his position, was interviewed at a nearby café. All interviews were semi-structured to allow flexibility in probing emerging subjects in the conversation and to give the respondents an opportunity to provide their full viewpoints (Flick, 2006; T. W. Lee, 1999).

As Hamada (2000) reasoned, a QM adoption process study cannot focus solely on the company's current state, which would overlook such issues as how the company came to be where it is today and where it is headed. Instead, the current focus is on "how events come into being and unfold over time in a context" (Halinen et al., 2012, p. 215). Therefore, the interviews concentrated on how and why the company had changed over the years, from the respective interviewees' perspectives.

A second round of interviews was conducted in mid-2012 with the owner and the acting production manager (referred to as Martin). The change leader was contacted, but he felt he had little new information to add since he had left the company. The purpose of the second round of interviews was to follow up on the QM at WashCo, focusing on what had happened since the last visit and the differences since the start of the process. Martin was asked about his role at the company, in particular how he worked with the improvements.

The interviews were recorded and transcribed with meaning condensation; that is, longer passage statements were condensed and abstracted and relevant material was ordered chronologically (Kvale and Brinkmann, 2009). The material was subsequently rewritten into narratives. For the first round of interviews, these narratives were shared and checked with the interviewees, which resulted in correction of certain details (such as dates of some events).

Secondary data was collected in two ways. First, financial data (turnover, profit, and employees) was extracted from the database "Affärsdata", which contains the annual reports of registered companies in Sweden. This data was normalised in order to maintain anonymity. Second, a report on a 2008 Six Sigma project conducted at WashCo provided further insight by detailing specific company improvement.

Different types of data (interviews, financial data, and a project report) have been used to triangulate the research results, as a means of strengthening the credibility of the study (Lincoln and Guba, 1985). The financial data is in turn compared with data from Statistics Sweden on turnover of the 269 Swedish companies classified in the same industry code (this data is available from 2007). 


\begin{tabular}{|c|c|c|}
\hline $\begin{array}{r}\text { Overview of } \\
\text { the case } \\
\text { study }\end{array}$ & $\begin{array}{l}\text { Theoretical } \\
\text { framework }\end{array}$ & $\begin{array}{l}\text { QM in SMEs } \\
\text { Adoption Processes }\end{array}$ \\
\hline \multirow[t]{3}{*}{$\begin{array}{r}\text { Field } \\
\text { procedures }\end{array}$} & Sources of data & $\begin{array}{l}\text { Employees' stories } \\
\text { Financial data } \\
\text { Improvement projects }\end{array}$ \\
\hline & $\begin{array}{l}\text { Procedures for data } \\
\text { collection }\end{array}$ & $\begin{array}{l}\text { Semi-structured interviews } \\
\text { Analysis of WashCo's financial development through public databases. } \\
\text { Analysis of report from a Six Sigma project at WashCo. }\end{array}$ \\
\hline & $\begin{array}{l}\text { Procedures for data } \\
\text { presentation }\end{array}$ & $\begin{array}{l}\text { To protect anonymity, company and interviewees names are changed to } \\
\text { fictive ones. Financial data are normalised. }\end{array}$ \\
\hline \multirow[t]{2}{*}{$\begin{array}{r}\text { Case study } \\
\text { questions }\end{array}$} & $\begin{array}{l}\text { Question areas } \\
\text { addressed in } \\
\text { interviews }\end{array}$ & $\begin{array}{l}\text { First round } \\
\text { Development of WashCo from start to modern production line. } \\
\text { View on quality and improvement work. } \\
\text { Quality improvements; start-up, challenges, improvement activities. } \\
\text { Second round } \\
\text { Development of WashCo since first round. } \\
\text { Current quality improvement activities. } \\
\text { Organization of QM efforts. }\end{array}$ \\
\hline & $\begin{array}{l}\text { Areas addressed } \\
\text { through analysis of } \\
\text { secondary data }\end{array}$ & $\begin{array}{l}\text { Types of improvement work that are conducted. } \\
\text { Development of WashCo during the period of initiation of QM, and } \\
\text { Swedish companies in the same industry during the same period. }\end{array}$ \\
\hline \multirow{3}{*}{$\begin{array}{r}\text { Case study } \\
\text { report }\end{array}$} & Outline & Narrative of a journey before, during and after the initiation of QM. \\
\hline & $\begin{array}{l}\text { Format for the } \\
\text { interview data }\end{array}$ & $\begin{array}{l}\text { Fictive company and interviewee names allow use of quotes and still } \\
\text { protect anonymity. }\end{array}$ \\
\hline & $\begin{array}{l}\text { Presentation of other } \\
\text { data }\end{array}$ & $\begin{array}{l}\text { Chart of company and industry development. } \\
\text { Table with key steps in WashCo's QM adoption process. }\end{array}$ \\
\hline
\end{tabular}

An additional approach to strengthen the reliability of a case study is through a so-called case study protocol (Yin, 2009). This protocol functions as a guide through the study and also provides an overview of data collection, analysis and presentation (see Table 1).

\section{The WashCo story}

WashCo is a small B2B business specialising in washing industrial containers. They see themselves as an economical and environmentally friendly alternative to buying new containers. The events described here revolve around decisions and actions taken at WashCo up to, and during, its journey towards a more structured way of working with improvements.

\section{The first part of the journey}

In early 2000, when John acquired WashCo, the procedures were for each of six operators in the production area to collect a container, bring it to his or her individual work area, perform the different cleaning activities, and return it. Job-shop-type work characterised the entire production floor. As the business expanded, effort was measured in sweat, and working on Saturdays was the norm. By 2005, the procedures were similar and the business had reached maximum capacity: there was simply no more room in the facility to expand without everyone getting in each other's way. John realised that something had to be done; however, he could not put his finger on what to do. Moving the business to larger facilities was not really an option. He visited other modern manufacturing plants, but could not relate their operations to WashCo. At this time, John's ideas and attempts to improve capacity involved doing the same steps faster: for example, by using quicker forklifts and stronger water pumps.

Meanwhile, John's brother Peter had finished his business studies and took a job at a consultancy; however, that company did not survive the 2005 economic downturn. Peter joined his brother's company as an operator in 2005 and realised the potential for improvements: "Everyone was working to the brink of exhaustion, but still couldn't catch up". Peter tried to apply Six Sigma methods, but the threshold was too high for WashCo at this time. After taking 
a course in lean production, Peter believed that WashCo's production needed to be ordered in a production line.

Peter tried to persuade John about this new way of working. He arranged workshops to demonstrate the efficiency of production lines, using stick figures as an example. To add credibility, he talked about how, "these methods are used by Toyota, the world's most efficient manufacturer". However, his attempts failed repeatedly, and he was reminded that WashCo did not produce cars, or stick figures, for that matter. After years of argument, Peter was about to give up. He clearly remembers the turning point when his mother suggested that he try to link to the business the ideas most familiar to John, such as the flow used in the slaughterhouse where John worked in his youth. Anecdotally, John told Peter, "When we stood by our workbench in the slaughterhouse and performed faster than the guy before us, we used to hit the metallic bench with our knives, producing a bellowing noise all around the premises." Peter retorted that that was like Toyota's "Kanban signal". With that, John began to understand what Peter was trying to communicate.

After that, Peter was able to present John with an idea for a suitable production line. The line would sequence the flow and automate major washing parts. Peter compared current cost with expected future cost, and found a technician to help build the line. The investment appeared sound, but WashCo lacked liquidity to implement the idea. John's philosophy had always been to earn money first and spend it later. Peter eventually convinced John to borrow the money, but the company's bank refused the loan. Peter argued that the investment was based on the value it could generate, while the bank valued the second-hand price of the components. After lengthy discussions, the banker stated, "If you had asked for money for a car that would have been another matter. But this ... I cannot understand". Without John's knowledge, Peter found a new bank that saw things differently, and the investment was underway.

Initially, the operators met the new plans with scepticism. There were complaints regarding the expected low stimulation of working in a line, as well as concerns for the lack of overtime and the attached extra payment. The interviewed production manager confirmed this view. However, WashCo was a small company, which meant everyone had to support the ownermanager. The production manager said he might have complained more in a larger company, but, "in a small company such as this, you work for the company and not for yourself". After a lengthy persuasion process, the idea was transformed into reality, and in 2007 the new production was up and running.

The second part of the journey

In the years following the production line's installation, the company's turnover and earnings have increased. Figure 2 shows the financial data for turnover, profit, and number of employees at WashCo, along with the average development of the turnover in the same industry. This data supports the premise that the new ways of working led to a positive development of the company. 


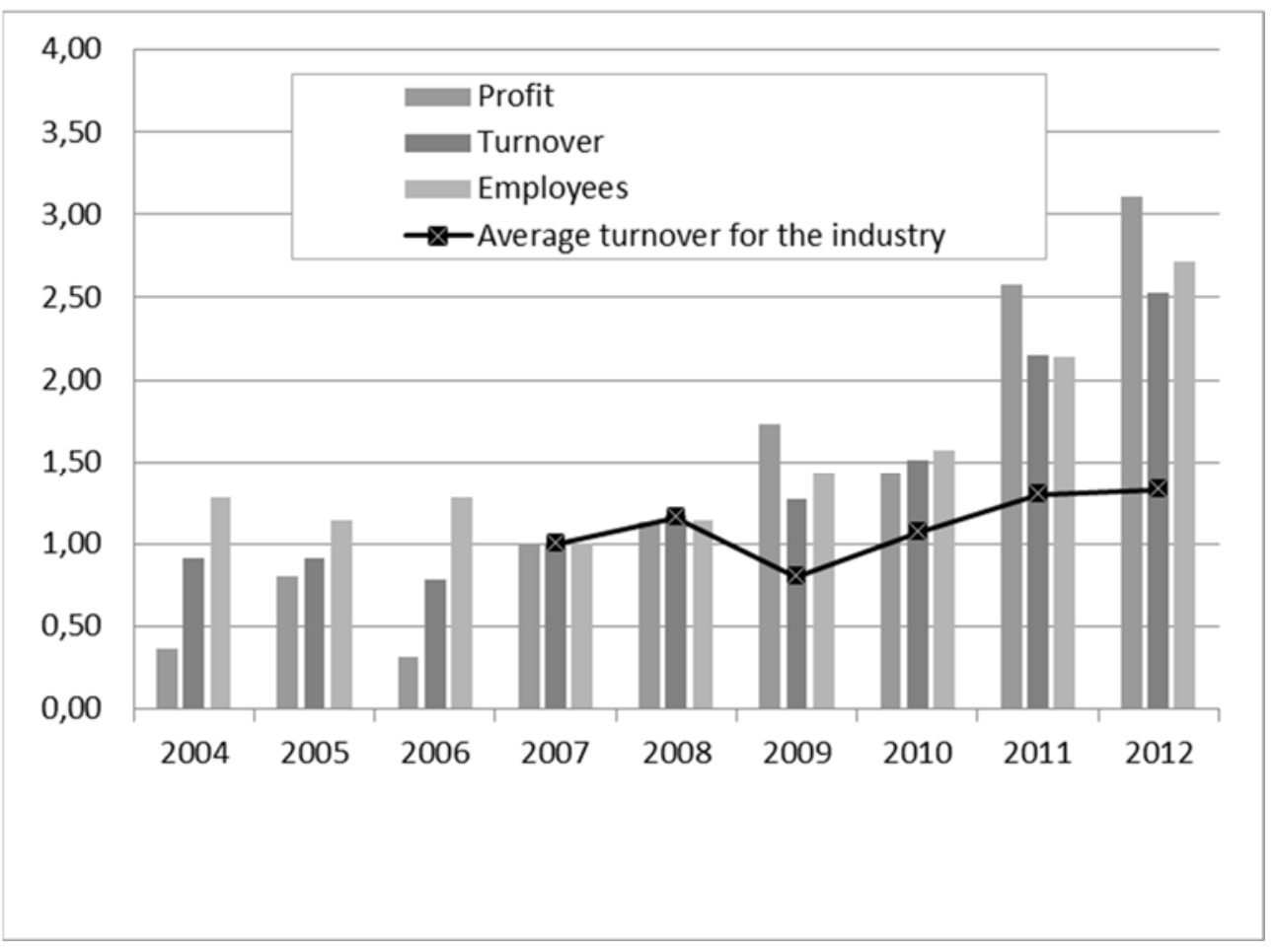

Figure 2. Financial data for WashCo. Normalised on the change of the production design in 2007. The line represents aggregated data for the industry (available from 2007).

It was further stated by the manager that the production capacity tripled after the first changes. WashCo is now among the largest players in its niche. Besides building a production line, the company has implemented other change initiatives. In 2008, a Six Sigma project to decrease the rejection rate on the line was carried out in collaboration with a university. The project was successful and reported a seven per cent rejection rate decrease. During the project, the employees were involved both to provide specialist input, and to be able to adopt suggested changes and sustain improvements. In the project, data collection was critical and required developing a measurement system, including checklists for employees on what to collect, and how. Hence, the project not only resulted in decreased rejection rates, but also other improvements that could support upcoming improvement initiatives.

The employees seem to appreciate the changes that have been made in WashCo. Although the mental stimulation from their work is comparable, the physical work conditions have improved. With the increased efficiency, they work fewer hours; however, they are still able to make good money as wage increases have followed the improved business results. The company also has hired additional workers because of the improved efficiency.

John acknowledged the mental journey that he and the rest of the employees have been on: "We spent quite some time in the office, drawing fishbone diagrams and learning words such as 'bottleneck', and I've had a hard time seeing the relevance for WashCo with all these bars in different colours. But now, when I know how to use them, I have a hard time seeing how you could improve a process - make an investment - without bars and diagrams. It simply is not possible."

John and Peter are convinced that their family relationship was a determining factor in this story. If an external consultant had offered to help, John would have been suspicious, not least because of the cost attached to the service. In addition, an external consultant would not have 
been able to do all that Peter did, such as visiting a new bank without the manager's consent. Peter believes that if he had been an external consultant, he would have quit long before any achievements had been made. Sometimes, the most positive response to Peter's methods was to ignore him, while the more negative ones came close to suggesting he was mentally disadvantaged.

In 2009, Peter quit the company to pursue new goals, and John saw no immediate need to replace him. Peter had already identified enough issues for WashCo to pursue, and there was not enough QM work to warrant a full-time position.

\section{The continued journey}

Three years later, in 2012, should WashCo have continued its change at breakneck speed, or should it have abruptly halted the new ways of working after the first successes? The truth seemed to lie somewhere in between. The company continued to grow gradually, and employed 17 people. The production line established in 2007 had by 2012 been physically extended. Other improvements made were mainly manifestations of ideas Peter had generated, and new ideas still raised scepticism. For example, before leaving the company, Peter spent a year emphasising the importance of maintenance and 5S, a workplace organisation method, but without success. When Peter left the company, John and the production manager began to drive the changes, giving Martin responsibility for standardising workplaces and proactive maintenance.

Martin said the company is still working to adopt more of Peter's ideas: "We have in essence gone through all Peter's suggestions now, but it has taken a long time to make them a natural part of how we do stuff around here." Some of Peter's suggestions, such as Monday morning meetings, were, by this time, a natural routine, while others, such as suggestion boards, were tried and failed. In the end, John stated, "I am now more receptive to new things: big things, small things, and not the least, my own thoughts. Now, I at least spend a night before rejecting new ideas."

\section{Analysis}

Many of the factors identified in research on QM in SMEs assume there is a conscious, planned initiative with some sort of company legitimacy (Assarlind and Gremyr, 2014). Based on this assumption, most research ignores the initiation stages (Zaltman et al., 1973), including giving advice on how to create knowledge of, and initial interest for, QM in the company. Most research instead implicitly "begins" at the start of a QM initiative already decided upon. However, the WashCo interviewees clearly describe the initial stages as being the most crucial segment.

Rogers (2003) argued that prior conditions, such as previous practices related to a new way of working, affect the adoption process. In the WashCo case, there was little to no prior experience of QM-related ideas and practices. The happenstance entry of Peter, educated in improvement methods, infused the firm with both the necessary awareness and the competence needed to commence QM work. For Peter, connecting a QM initiative to previous practices or a perceived need was a necessary challenge. In this specific case, the owner's personal experiences were key during the first persuasion stage. In fact, the owner-manager John was described as actively opposing new practices in the beginning, and it took more than a year before he viewed Peter's ideas as reasonable enough to try. The literature has indeed pointed out the necessity of contextualising QM to a specific SME, rather than using large company initiatives as a roadmap (e.g., Rahman and Tannock, 2005; Salaheldin, 2009; Thomas and Webb, 2003). However, the WashCo story demonstrates that such contextualisation is not only part of detailed planning, 
and thus the implementation stage of a QM initiative; it must also be part of the knowledge and persuasion stages.

The interviewees were, furthermore, convinced that the blood relationship between Peter and John made the transformation possible, whereas, for example, an external consultancy firm never would have been able to succeed. For instance, Peter independently, and against repeated opposition by John, used his competence to adapt ideas to the context of WashCo and even went so far as to initiate bank contacts to fund his ideas. In Rogers's (2003) terms, the persuasion stage was critically important, and the tipping point occurred when John decided to try some of Peter's proposals. The initiation (Zaltman et al., 1973), consisting of the knowledge and persuasion stages (Rogers, 2003) and leading to the decision to adopt, was critical for QM adoption in this SME.

Once management was on board, the changes in the first part of the journey were described as comparatively simple to implement because of employee loyalty. The closeness between employees and management in SMEs often makes it easier to move the whole company in the same direction (Ahire and Golhar, 1996; Ghobadian and Gallear, 1997).

Following production line creation, the owner-manager was ready to continue with more improvement ideas. Once the adoption of QM passed a confirmation stage (Rogers, 2003), employees felt they did the same work, but more efficiently and with potentially better quality, which aligns with suggestions for improving old ways and goals rather than introducing new ones (Ghobadian and Gallear, 1997; Salaheldin, 2009; Thomas and Webb, 2003). The events that took place during the first part of the story, which culminated in the production line installation, thus paved the way for further improvement. Over time, the adoption of QM at WashCo can be seen as having aligned well with gradual implementation procedures (Ghobadian and Gallear, 1997; Salaheldin, 2009; Struebing and Klaus, 1997; Thomas and Webb, 2003; Yusof and Aspinwall, 2000). An overview of the adoption process is displayed in Table 2.

Table 2. Overview of the QM adoption process at WashCo

\begin{tabular}{|c|c|c|c|c|c|}
\hline & Knowledge & Persuasion & Decision & Implementation & Confirmation \\
\hline First part & $\begin{array}{l}\text {-Peter joined } \\
\text {-Workshops } \\
\text { on lean ideas }\end{array}$ & $\begin{array}{l}\text {-Failed attempt } \\
\text { with Six Sigma } \\
\text {-Years of } \\
\text { argumentation } \\
\text {-Idea of } \\
\text { production line }\end{array}$ & $\begin{array}{l}\text {-To construct } \\
\text { a production } \\
\text { line }\end{array}$ & $\begin{array}{l}\text {-Bank approval } \\
\text {-Production line }\end{array}$ & $\begin{array}{l}\text {-General positive } \\
\text { attitude to the } \\
\text { new ways of } \\
\text { working }\end{array}$ \\
\hline Second part & $\begin{array}{l}\text {-University } \\
\text { competence } \\
\text { on Six Sigma }\end{array}$ & $\begin{array}{l}\text {-Potential of QM } \\
\text { ideas realised } \\
\text { after events in } \\
\text { first part }\end{array}$ & $\begin{array}{l}\text {-To try new } \\
\text { improvement } \\
\text { initiatives }\end{array}$ & $\begin{array}{l}\text {-Six Sigma project } \\
\text {-Measurement } \\
\text { system }\end{array}$ & $\begin{array}{l}-7 \% \text { reduction of } \\
\text { rejection rate }\end{array}$ \\
\hline Continuation & & $\begin{array}{l}\text {-Further potential } \\
\text { of QM ideas, } \\
\text { including } \\
\text { continuous } \\
\text { improvements, } \\
\text { realised after } \\
\text { events in second } \\
\text { part }\end{array}$ & $\begin{array}{l}\text {-To appoint a } \\
\text { person } \\
\text { continuing } \\
\text { trying new } \\
\text { improvement } \\
\text { ideas }\end{array}$ & $\begin{array}{l}\text {-Physical } \\
\text { extension of the } \\
\text { line } \\
\text {-Monday morning } \\
\text { meetings } \\
\text {-System for } \\
\text { continuous } \\
\text { improvements }\end{array}$ & $\begin{array}{l}\text {-The organisation } \\
\text { stepped up and } \\
\text { took ownership } \\
\text { of the process, } \\
\text { after the } \\
\text { departure of John }\end{array}$ \\
\hline
\end{tabular}


Compared with Rogers's (2003) innovation decision model, the case did not follow a straightforward process. Once John was persuaded to consider Peter's ideas, he did not proceed immediately with a full-fledged QM adoption, but instead tried one proposal (the production line). Currently, more and more QM ideas have gained ground in the company; the QM adoption process has been iterative, further aligning with the literature's gradual implementation emphasis.

The iterative approach can be exemplified by the application of Six Sigma. The first attempt in 2005 failed and the associated methods were deemed not to be appropriate for WashCo. The second attempt in 2008 resulted in successful production process improvements. Even within this project, iterative developments took place, for example, a measurement system was developed that could also be of use to support upcoming improvement initiatives.

The developments during the second part, including this Six Sigma project, further demonstrated the value of QM ideas to the organisation, leading to further improvements, even though Peter by this time had left the organisation. For example, John expanded the production line, and Martin was assigned to work with standardisation and has since started to work with new improvements, although he has been restricted to the ideas suggested by Peter before his departure. The case thus supports Rahman and Tannock's (2005) statement that external support and competence is needed, at least eventually, to continue facilitating the process. Without this drive forward, there is a considerable risk that the development may halt, or start to regress (Assarlind and Aaboen, 2014).

\section{Discussion}

Four critical QM adoption aspects emerged from the WashCo study: the importance of initiation, the importance of contextualisation, QM adoption as an iterative process, and the need for external support.

The literature offers limited insight regarding how to approach an owner-manager who at first is not interested in QM. Most research, even that which emphasises committed leadership (e.g., Beheshti and Lollar, 2003; Hansson and Klefsjö, 2003; Tannock et al., 2002), assumes that management at least does not put up active opposition. Some literature does suggest measures for convincing hesitant management, such as focusing on early positive results (Yusof and Aspinwall, 2000). However, it is still assumed that there will be an opportunity to show potential QM benefits. Just as Ghobadian and Gallear (1996, p. 91) stated, "Probably the biggest obstacle to the introduction of [QM] in SMEs is the 'management realisation' and the ability of owner managers to modify their behaviour and management style." This statement is close to what Rogers (2003) referred to as the knowledge and persuasion stages (see

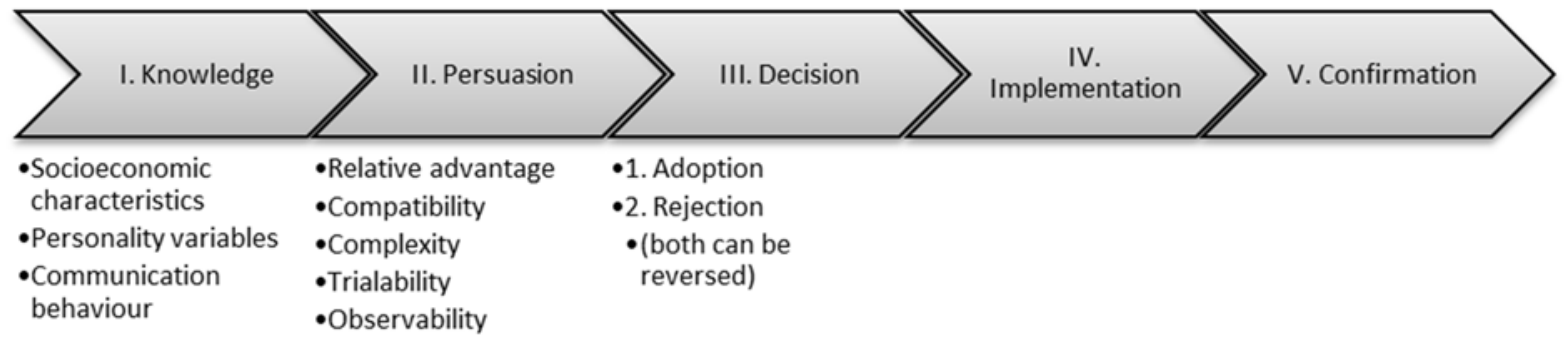

Figure 1), on which current literature on QM in SMEs does not focus. The episode in which the change manager at WashCo was able to connect his ideas to the owner's "reality" - his experience in the slaughterhouse - became a "tipping point", enabling the owner to make an initial decision to try the proposal. 
This case further demonstrates that improvement methods that have proven valuable in large companies, including Six Sigma and Lean, can certainly aid smaller companies if contextualised to the SME's reality. No "new" tools were needed, but rather a broad knowledge of generic improvement methodologies and the ability to identify what fits where and when. The categories on QM in SMEs, such as employee involvement (Kumar and Antony, 2008; Rahman and Tannock, 2005) and external support involvement (G. L. Lee and Oakes, 1995; Rahman and Tannock, 2005), focus on the implementation stage of Rogers's (2003) innovation decision model. However valuable, this study shows that other stages of the model also are critical. The categories of contextualisation and gradual implementation (Assarlind and Gremyr, 2014) play a role in the knowledge and persuasion stages (see

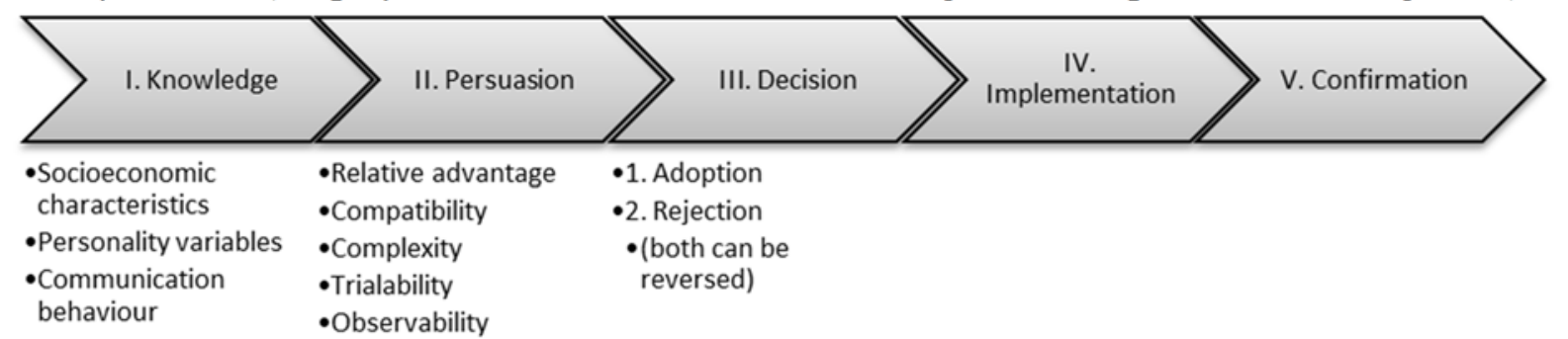

Figure 1). By applying the adoption process perspective, practitioners and academics alike can better understand the function of advice from different categories of critical factors for QM in SMEs, and thus apply them more effectively to their contexts.

Had the adoption of QM at WashCo halted after the production line installation, it would probably be a stretch to call it QM work (at least if subscribing to notions by, for example, Lascelles and Dale, 1991). However, this installation was only the first step in what would become a more systematic effort. Besides the operational benefits, the production line paved the way for other QM ideas to be considered. As an example, Six Sigma ideas did not gain early stage acceptance because they were too far removed from previous practice or perceived needs, but were successful at a later stage. As seen in Table 2, the second attempt was preceded by addition of new competence from a university and a realisation of the potential of QM ideas as a result of the first changes. This scenario points to an important aspect of QM adoption that descriptions, such as Rogers's (2003), do not fully cover; namely, the iterative nature of the process. Introducing the production line can be seen as an adoption process in itself (albeit perhaps not of systematic QM work), but it can also be seen as the first QM adoption process iteration.

A small company often lacks the financial clout (Jones et al., 2005) to employ a full-time change champion (Yusof and Aspinwall, 2000), which is why Peter left the company. Authors such as G. L. Lee and Oakes (1995) and Rahman and Tannock (2005) suggested that society has an interest in supporting smaller companies and helping them with training and change expertise. The WashCo case encourages this approach through which a change expert may bring new knowledge into a company. However, as in the case of Peter, schooled improvement experts are probably discouraged by the idea of spending 90 percent of their time driving forklifts. Furthermore, WashCo may have been sceptical about a consultancy firm's agenda, which is the argument Thomas and Webb (2003) made. A governmental body that would declare its only agenda to be to help, as Thomas and Webb (2003) suggested, may be able to address some of these issues. 


\section{Conclusions}

This study of WashCo's journey illuminates critical aspects of a QM initiative in a small company during an adoption process and points to four critical areas: the importance of initiation, the importance of contextualisation, QM adoption as an iterative process, and the need for external support. New methods are not necessarily needed to improve operations in small companies, as standard QM methods can be used with potency if they are sensibly contextualised. The tipping point is when the manager sees connections to critical organisational needs and agrees to try new ways of working. The literature on QM initiatives in SMEs to date has focused on the stages that follow an actual decision to begin a QM initiative. But in this study, these latter phases were less critical (once the manager was on board, involvement from employees followed), which points out the need for additional research on the QM adoption process initiation stages in SMEs.

\section{References}

Ahire, S. L. and Golhar, D. Y. (1996), "Quality management in large vs small firms", Journal of Small Business Management, Vol. 34 No. 2, pp. 1-13.

Ahlström-Söderling, R. (2003), "SME strategic business networks seen as learning organizations", Journal of Small Business and Enterprise Development, Vol. 10 No. 4, pp. 444-454.

Antony, J. (2008), "Can Six Sigma be effectively implemented in SMEs?", International Journal of Productivity and Performance Management, Vol. 57 No. 5, pp. 420 - 423.

Assarlind, M. and Aaboen, L. (2014), "Forces affecting one Lean Six Sigma adoption process", International Journal of Lean Six Sigma, Vol. 5 No. 3, pp. 324-340.

Assarlind, M. and Gremyr, I. (2014), "Critical factors for quality management initiatives in small and medium-sized enterprises", Total Quality Management \& Business Excellence, Vol. 25 No. 3-4, pp. 397-411.

Beheshti, H. M. and Lollar, J. G. (2003), "An empirical study of US SMEs using TQM", Total Quality Management \& Business Excellence, Vol. 14 No. 8, pp. 839-847.

Bergman, B. and Klefsjö, B. (2010), Quality: From Customer Needs to Customer Satisfaction (3rd ed.), Studentlitteratur, Lund.

Birkinshaw, J., Hamel, G. and Mol, M. J. (2008), "Management Innovation", Academy of Management Review, Vol. 33 No. 4, pp. 825-845.

Bridge, S., O'Neill, K. and Cromie, S. (2003), Understanding Enterprise, Entrepreneurship, and Small Business, Palgrave Macmillan, New York.

Brown, A. (2013), "Quality: where have we come from and what can we expect?", The TQM Journal, Vol. 25 No. 6, pp. 585-596.

Brue, G. (2006), Six Sigma for Small Business, Entrepreneur Media, Inc., Madison, WI.

Dahlgaard, J. J. and Dahlgaard-Park, S. M. (2006), "Lean production, Six Sigma quality, TQM and company culture", The TQM Magazine, Vol. 18 No. 3, pp. 263-281.

Damanpour, F. (1992), "Organizational size and innovation", Organization Studies, Vol. 13 No. 3, pp. 375-402.

Dane, F. C. (1990), Research Methods, Brooks/Cole, Pacific Grove.

Danes, S. M., Loy, J. T.-C. and Stafford, K. (2008), "Business planning practices of familyowned firms within a quality framework", Journal of Small Business Management, Vol. 46 No. 3, pp. 395-421.

Dean, J. W., Jr. and Bowen, D. E. (1994), "Management theory and total quality: Improving research and practice through theory development", The Academy of Management Review, Vol. 19 No. 3, pp. 392-418.

Dubois, A. and Gadde, L.-E. (2002), "Systematic combining: An abductive approach to case research", Journal of Business Research, Vol. 55 No. 7, pp. 553-560. 
Eisenhardt, K. M. (1989), "Building theories from case study research", The Academy of Management Review, Vol. 14 No. 4, pp. 532-550.

Flick, U. (2006), An Introduction to Qualitative Research, Sage Publications, London.

Ghobadian, A. and Gallear, D. N. (1996), "Total quality management in SMEs", Omega, Vol. 24 No. 1, pp. 83-106.

Ghobadian, A. and Gallear, D. N. (1997), "TQM and organization size", International Journal of Operations \& Production Management, Vol. 17 No. 2, pp. 121-163.

Hackman, J. R. and Wageman, R. (1995), "Total quality management: Empirical, conceptual, and practical issues", Administrative Science Quarterly, Vol. 40 No. 2, pp. 309-342.

Halinen, A., Medlin, C. J. and Törnroos, J.-Å. (2012), "Time and process in business network research", Industrial Marketing Management, Vol. 41 No. 2, pp. 215-223.

Hamada, T. (2000). "Quality as a cultural concept: Messages and metamessages". In R. E. Cole \& R. W. Scott (Eds.), The Quality Movement \& Organization Theory, Sage Publications, London, pp. 295-312.

Hansson, J. and Klefsjö, B. (2003), "A core value model for implementing total quality management in small organisations", The TQM Magazine, Vol. 15 No. 2, pp. 71-81.

Jarvis, R. (2006). "Finance and the small business". In S. Carter \& D. Jones-Evans (Eds.), Enterprise and Small Business: Principles, Practice and Policy (2nd ed.), FT Prentice Hall, Harlow, pp. 338-356.

Jones, S. C., Knotts, T. L. and Brown, K. L. (2005), "Selected quality practices of small manufacturers", The Quality Management Journal, Vol. 12 No. 1, pp. 41-53.

Kimberly, J. R. and Evanisko, M. J. (1981), "Organizational innovation: The influence of individual, organizational, and contextual factors on hospital adoption of technological and administrative innovations", The Academy of Management Journal, Vol. 24 No. 4 , pp. 689-713.

Kumar, M. and Antony, J. (2008), "Comparing the quality management practices in UK SMEs", Industrial Management \& Data Systems, Vol. 108 No. 9, pp. 1153-1166.

Kuratko, D. F., Goodale, J. C. and Hornsby, J. S. (2001), "Quality practices for a competitive advantage in smaller firms", Journal of Small Business Management, Vol. 39 No. 4, pp. 293-311.

Kvale, S. and Brinkmann, S. (2009), Den Kvalitativa Forskningsintervjun (S.-E. Torhell, Trans. 2nd ed.), Studentlitteratur, Lund.

Lascelles, D. M. and Dale, B. G. (1991), "Levelling out the future", The TQM Magazine, Vol. 3 No. 6 , pp. 325-330.

Lee, G. L. and Oakes, I. (1995), "The pros and cons of total quality management for smaller firms in manufacturing: Some experiences down the supply chain", Total Quality Management, Vol. 6 No. 4, pp. 413-426.

Lee, T. W. (1999), Using Qualitative Methods in Organizational Research, Sage Publications, Thousand Oaks, CA.

Lincoln, Y. and Guba, E. (1985). Naturalistic Inquiry. Sage Publications, Beverly Hills

Martinez-Costa, M. and Jimenez-Jimenez, D. (2009), "The effectiveness of TQM: The key role of organizational learning in small businesses", International Small Business Journal, Vol. 27 No. 1, pp. 98-125.

Pun, K. F. and Jaggernath-Furlonge, S. (2012), "Impacts of company size and culture on quality management practices in manufacturing organisations: An empirical study", The TQM Journal, Vol. 24 No. 1, pp. 83-101.

Rahman, M. N. A. and Tannock, J. D. T. (2005), "TQM best practices: Experiences of Malaysian SMEs", Total Quality Management \& Business Excellence, Vol. 16 No. 4, pp. 491-503.

Rogers, E. M. (2003), Diffusion of Innovations (5th ed.), Free Press, New York. 
Salaheldin, S. I. (2009), "Critical success factors for TQM implementation and their impact on performance of SMEs", International Journal of Productivity and Performance Management, Vol. 58 No. 3, pp. 215-237.

Struebing, L. and Klaus, L. A. (1997), "Small businesses thinking big", Quality Progress, Vol. 30 No. 2, pp. 23-27.

Tannock, J., Krasachol, L. and Ruangpermpool, S. (2002), "The development of total quality management in Thai manufacturing SMEs: A case study approach", International Journal of Quality \& Reliability Management, Vol. 19 No. 4, pp. 380-395.

Thomas, A. and Webb, D. (2003), "Quality systems implementation in Welsh small- to medium-sized enterprises: a global comparison and a model for change", Proceedings of the Institution of Mechanical Engineers, Part B: Journal of Engineering Manufacture, Vol. 217 No. 4, pp. 573-579.

Valmohammadi, C. (2011), "The impact of TQM implementation on the organizational performance of Iranian manufacturing SMEs", The TQM Journal, Vol. 23 No. 5, pp. 496-509.

Welsh, J. A. and White, J. F. (1981), "A small business is not a little big business", Harvard Business Review, Vol. 59 No. 4, pp. 18-27.

Yin, R. K. (2009), Case Study Research - Design and Methods (4 ${ }^{\text {th }}$ ed.), Sage Publications, Thousand Oaks

Yusof, S. R. M. and Aspinwall, E. (1999), "Critical success factors for total quality management implementation in small and medium enterprises", Total Quality Management, Vol. 10 No. 4-5, pp. 803-809.

Yusof, S. R. M. and Aspinwall, E. (2000), "TQM implementation issues: review and case study", International Journal of Operations \& Production Management, Vol. 20 No. 6, pp. 634-655.

Zaltman, G., Duncan, R. and Holbek, J. (1973), Innovations and Organizations, John Wiley \& Sons, New York. 